\title{
PERTANGGUNGJAWABAN PENYANDERAAN (GIJZELING) TERHADAP PENANGGUNG PAJAK
}

\author{
Julius Sujianto \\ Program Studi Magister Kenotariatan, Universitas Airlangga \\ e-mail:julius@buddhist.com
}

\begin{abstract}
ABSTRAK
Pajak merupakan iuran terutang yang wajib dibayarkan kepada negara baik oleh orang perorangan atau badan yang sifatnya memaksa sesuai ketentuan undang-undang sehingga kepada tiap-tiap individu ataupun badan yang memenuhi kriteria sebagai wajib pajak mempunyai utang pajak wajib dibayar. Apabila utang pajak tersebut tidak dibayarkan, maka dapat diterapkan upaya penyanderaan. Penyanderaan dalam hukum perpajakan diatur dalam Undang-Undang No. 19 Tahun 2000 dan yang memikul beban tanggung jawab ialah wajib pajak, baik perorangan maupun badan hukum sesuai isi Surat Perintah Penyanderaan. Penelitian yuridis normatif ini bertujuan untuk menganalisa pihak-pihak yang dimaksud sebagai penanggung pajak serta kedudukannya dan tanggungjawabnya dalam sistem hukum perpajakan, pihak yang memangku beban tanggung jawab dalam upaya penyanderaan serta upaya hukum yang dapat ditempuh oleh penanggung pajak yang telah dilakukan tindakan penyanderaan. Penelitian ini menyarankan perlunya revisi peraturan tentang penagihan pajak melalui Surat Pajak terhadap pihak yang memikul tanggung jawab saat dilakukan tindakan penyanderaan, hal ini disebabkan Penanggung Pajak merupakan wakil dari Wajib Pajak dalam keadaan tertentu sembari tetap meningkatkan sosialisasi kepatuhan pajak kepada masyarakat.
\end{abstract}

Kata Kunci: penanggung pajak; tanggung jawab; penyanderaan

\section{ABSTRACT}

Taxes are like debts that must be paid to the state either by individuals or entities that are coercive according to law so that each individual or entity that meets the criteria as a taxpayer has a tax debt that must be paid. If the tax debt has not been paid, then hostage measures can be applied. Hostage in tax law was regulated in Act No. 19 of 2000 and those who bear the burden of responsibility are taxpayers, both individuals and legal entities according to the contents of the Hostage Order. This normative juridical research aims to analyze the parties referred to as tax bearers and their positions and responsibilities in the tax law system, those who carry the burden of responsibility in taking hostage efforts and legal remedies that can be taken by tax bearers who have taken hostage actions. This research suggests the need for a revision of regulations regarding tax collection through Tax Letters against those who bear responsibility when taking hostage action, this is because the Tax Insurer is a representative of the Taxpayer in certain circumstances while still increasing the socialization of tax compliance to the public.

Keywords: taxpayer; responsibility; hostage

\section{PENDAHULUAN}

Indonesia sebagai satu di antara sekian banyak negara yang berkembang pada saat ini juga sedang melakukan pembangunan dan pengembangan sarana maupun prasarana, maupun dalam bidang hukum, ekonomi, politik, budaya serta keamanan.
Pembangunan tersebut adalah untuk supaya kesejahteraan rakyat Indonesia semakin meningkat. Pembangunan dan pengembangan yang dilakukan tersebut tentunya memerlukan dana yang sangat besar. 
Negara mempunyai beberapa sumber penerimaan sebagai berikut: 1. Pajak; 2. Kekayaan alam; 3. Retribusi; 4. Iuran; 5. Sumbangan; 6. Laba dari Badan Usaha Milik Negara; 7. Sumber-sumber lainnya. ${ }^{1}$

Kekayaan alam yang ada di Indonesia cukup melimpah, terutama dari sektor batu bara, minyak bumi dan gas, emas. Akan tetapi kekayaan alam tersebut tidak dapat diperbaharui, sehingga akan dapat habis suatu saat nanti. Oleh karena itu, negara mencari sumber penerimaan negara lainnya, yaitu pajak. Pada saat ini pajak merupakan sumber utama dari pendapatan negara.

Menurut Rochmat Soemitro, Pajak merupakan kontribusi rakyat yang wajib dibayarkan ke kas negara sesuai ketentuan peraturan perundangundangan, dan tidak mendapatkan jasa-timbal (kontra-prestasi), yang dapat dirasakan langsung dan dipergunakan untuk membayarkan pengeluaran negara secara umum. ${ }^{2}$ Dapat dipaksakan artinya apabila terdapat suatu utang pajak yang belum atau tidak terbayarkan, sehinga atas utangnya tersebut dapat dilakukan penagihan dengan cara menerbitkan surat paksa, melaksanakan penyitaan, dan bahkan dapat dilakukan dengan penyanderaan.

Dari pengertian tersebut dapat dirumuskan beberapa unsur-unsur, sebagai berikut: pertama, Pajak yang dibayarkan wajib didasarkan peraturan perundang-undangan; kedua, Sifatnya dapat dipaksakan; ketiga, Wajib Pajak tidak merasakan langsung imbalan atas utang pajak yang telah dibayarkan; keempat, Pajak dipungut oleh negara dalam hal ini adalah Pemerintah, baik itu dipungut oleh Pemerintah Pusat melalui Kementerian Keuangan ataupun oleh Pemerintah Daerah; dan kelima, Pajak yang telah dibayarkan tersebut dipergunakan untuk pembiayaan pengeluaran rutin atau pembangunan pemerintah untuk kepentingan umum. $^{3}$

Dalam hukum perpajakan yang menjadi subjek hukum adalah subjek pajak. Subjek Pajak sebagaimana dimaksud oleh UU No. 7 Tahun 1983

${ }^{1}$ Erly Suandy. (2016). Hukum Pajak Edisi 7. Jakarta: Salemba Empat, h. 2.

${ }^{2}$ Ida Zuraida dan L.Y. Hari Sih Advianto. (2011). Penagihan Pajak: Pajak Pusat dan Pajak Daerah. Bogor: Ghalia Indonesia, h. 3 .

${ }^{3}$ Wirawan B. Ilyas dan Richard Burton. (2010). Hukum Pajak Edisi 5. Jakarta: Salemba Empat, h. 7. sebagaimana telah diubah beberapa kali terakhir dengan UU No. 36 Tahun 2008 tentang Pajak Penghasilan (selanjutnya disebut UU PPh), pada Pasal 2 ayat (1), terdiri dari: a. Orang pribadi; b. Warisan yang belum dibagikan kepada ahli waris atau warisan tidak bertuan; c. Badan; dan d. Bentuk Usaha Tetap (BUT).

Dalam hukum perpajakan subjek pajak tersebut memiliki kewajiban perpajakan sebagimana ditentukan oleh peraturan perundang-undangan perpajakan, dan subjek pajak tersebut berkedudukan sebagai wajib pajak. Kewajiban perpajakan tersebut adalah membayar pajak terutang atau disebut utang pajak. Pada umumnya pajak terutang muncul berdasarkan undang-undang, dimana telah terpenuhinya suatu tatbestand, yaitu rangkaian perbuatan, keadaan, dan peristiwa yang berakibat timbulnya utang pajak sebagaimana diatur dalam peraturan perundang-undangan perpajakan. ${ }^{4}$ Selain itu, utang pajak juga muncul karena telah dikeluarkan surat yaitu surat ketepan pajak.

Ketika utang pajak tidak dibayarkan, maka fiskus dapat melakukan tindakan penagihan dengan surat paksa yaitu penyanderaan. Sebelum melakukan tindakan penyanderaan, fikus melakukan tindakan penagihaan pajak pasif dengan menggunakan surat penagihan pajak atau dikenal dengan STP dan Surat Ketetapan Pajak (baik SKPKB maupun SKPKBT). Apabila WP masih tidak membayar utang pajak tersebut, maka fiskus akan melakukan penagihan pajak aktif melalui Surat Teguran sampai dengan penyanderaan dan penyitaan kepada WP maupun penanggung pajak.

Penyanderaan sebagaimana diatur pada Pasal 1 di angka 21 Undang-Undang Nomor 19 Tahun 2000 tentang Penagihan Pajak Dengan Surat Paksa (selanjutnya disebut UU PPSP) adalah pembatasan kebebasan penanggung pajak untuk waktu tertentu dan ditempatkan di tempat tertentu. Berdasarkan Pasal 33 UU PPSP mengatur bahwa penyanderaan hanya dapat dilakukan ketika penanggung pajak mempunyai utang pajak sekurang-kurangnya Rp100.000.000,00 (seratus juta rupiah) serta diragukan itikadnya untuk melunasi utang pajak tersebut.

Pengertian penanggung pajak sendiri diatur pada Pasal 1 di angka 3 UU PPSP, ialah orang perorangan atau badan yang bertanggungjawab

${ }^{4}$ Erly Suandy. op.cit., h. 128. 
terhadap pembayaran pajak, termasuk wakilnya yang melaksanakan dan menjalankan kewajiban WP berdasarkan ketentuan undang-undang perpajakan. Dari pengertian tersebut masih terdapat hal-hal yang kabur terkait pihak-pihak mana saja yang termasuk dalam pengertian penanggung pajak tersebut yang memikul beban tanggung jawab ketika dilaksanakannya upaya penyanderaan tersebut serta apakah hanya penanggung pajak saja yang dapat dikenakan tindakan penyanderaan.

\section{RUMUSAN MASALAH}

Berdasarkan uraian latar belakang masalah, penelitian ini mengkaji tentang batasan pihakpihak yang dapat digolongkan sebagai penanggung pajak serta bagaimana kedudukan hukum dan tanggungjawabnya dalam sistem hukum perpajakan dan pihak-pihak mana saja yang memikul beban tanggung jawab dalam upaya penyanderaan.

\section{METODE PENELITIAN}

Penelitian ini menggunakan penelitian hukum normatif. Pendekatan masalah yang dipergunakan ialah statute approach dan conceptual approach. Statute approach adalah pendekatan dengan melihat isi atau substansi peraturan perundang-undangan yang terkait dengan permasalahan yang diteliti, diantaranya UU No. 6 Tahun 1983 yang telah beberapa kali diubah, terakhir dengan UU No. 28 Tahun 2007 dan UU No. 16 Tahun 2009 tentang Ketentuan Umum dan Tata Cara Perpajakan, UU No. 19 Tahun 1997 sebagaimana diubah dengan UU No. 19 Tahun 2000 tentang PPSP, dan peraturan lain yang terkait. Conceptual approach beranjak dari pendapat para ahli yang terus berkembang di dalam ilmu hukum sehingga akan ditemukan pemikiran yang akan melahirkan pengertian baru atas hukum yang berlaku saat ini, konsep-konsep hukum, serta asas hukum yang sesuai dalam permasalahan yang diteliti. $^{5}$

\section{PEMBAHASAN}

\section{Sistem Perpajakan, Wajib Pajak, dan Penanggung Pajak}

Pajak merupakan sumber pendapatan utama negara Indonesia. Untuk itu perlu adanya suatu sistem

\footnotetext{
5 Peter Mahmud Marzuki. (2005). Penelitian Hukum. Jakarta: Prenada Media, h. 95.
}

perpajakan yang baik sehingga tidak merugikan masyarakat selaku Wajib Pajak dan menaikkan pendapatan negara dalam bidang perpajakan di Indonesia. Untuk menciptakan rasa keadilan dalam pemungutan pajak harus didasarkan pada asas-asas pemungutan pajak. Terdapat empat asas dalam pemungutan pajak, atau disebut dengan four cannons/ the four maxims, ${ }^{6}$ yaitu:

Pertama, Equality. Pajak yang dibebankan kepada subjek atau dalam hal ini subjek pajak harusnya seimbang antara kemampuan WP dalam membayar pajak seimbang atau setara dengan pendapatan yang diterima di dalam lindungan pemerintah. Jadi, dalam asas equality tidak dibenarkan negara mendiskriminasi di antara Wajib Pajak. Pada saat yang sama, Wajib Pajak harus diperlakukan sama (dikenakan pajak yang sama).

Kedua, Certainly. Utang Pajak yang dibayarkan WP wajib jelas dan tidak ada kompromis (not arbitrary). Pada asas ini, diharapkan adanya kepastian hukum terkait siapa saja yang menjadi subjek pajak, apa saja yang menjadi objek pajak, berapakah tarif pajak yang dikenakan serta ketentuan terkait tata cara pembayaran dan pelaporan pajak.

Ketiga, Convenience of payment. Pajak hendaknya dipungut pada saat yang paling baik bagi Wajib Pajak, yaitu saat sedekat-dekatnya dengan saat diterimanya penghasilan/keuntungan yang dikenakan pajak.

Keempat, Economic of collections. Dalam melaksanakan pemungutan atas pajak terutang seharusnya dilaksanakan dengan cara sehematnya (seefisien), dan tidak boleh apabila biaya untuk memungut pajak terutang lebih besar daripada penerimaan pajak tersebut. Tidak akan ada hasilnya apabila biaya yang harus dikeluarkan lebih besar dibandingkan dengan penerimaan pajak tersebut.

Sistem pengungutan pajak berdasarkan pihak yang menetapkan pajaknya terbagi atas empat macam, yaitu official assessment system, semiself assessment system, self assessment system, dan witholding system?

Pertama, Sistem Official assessment merupakan salah satu sistem dalam upaya pemungutan terhadap pajak yang memberikan kewenangan pada pemungut pajak (fiskus) untuk menentukan besaran utang pajak

\footnotetext{
${ }^{6}$ Erly Suandy, loc.cit.

${ }^{7}$ Wirawan B. Ilyas dan Richard Burton. loc.cit.
} 
yang wajib dibayarkan oleh WP, dengan menerbitkan surat ketepapan pajak. ${ }^{8}$

Pada sistem pemungutan pajak ini WP bersifat pasif dan hanya menunggu sampai fiskus mengeluarkan surat ketetapan pajak. Besaran utang pajak baru dapat diketahui setelah diterbitkannya surat berupa SKP (Surat Ketetapan Pajak). Ciriciri dari official assessment system adalah: a. Kewenangan dalam menentukan besaran utang pajak ada pada fiskus (pemungut pajak); b. Wajib Pajak bersifat pasif; c. Utang pajak timbul ketika SKP (Surat Ketetapan Pajak) telah dikeluarkan.

Kedua, Sistem Semiself assessment ialah suatu sistem dalam pemungutan pajak dimana memberikan kewenangan pada pemungut pajak (fiskus) serta WP dalam menentukan besaran utang pajak yang wajib dibayarkan oleh WP.

Pada sistem Semiself assessment ini, diawal tahun WP dapat menentukan besaran utang pajak yang akan dibayarkan untuk tahun berjalan yang merupakan angsuran pajak yang disetor sendiri oleh Wajib Pajak. Selanjutnya diakhir tahun pajak tersebut, barulah pemungut pajak (fiskus) yang berwenang untuk menentukan besaran pajak yang terutang yang sebenarnya didasarkan pada data yang telah dilaporkan WP selama tahun berjalan sebelumnya.

Ketiga, Sistem Self assessment ialah suatu sistem dalam pelaksanaan pemungutan pajak yang memberikan kewenangan secara penuh kepada WP untuk menghitung sendiri, membayar sendiri, serta melaksanakan pelaporan besaran pajak terutang sendiri.

Pada sistem pemungutan pajak ini WP secara aktif menghitung dan menentukan besaran utang pajaknya dan fiskus tidak ikut menentukan besarnya pajak terutang, kecuali ketika WP melakukan pelanggaran terhadap ketentuan yang ada.

Sistem ini umumnya diterapkan dalam jenisjenis pajak yaitu yang WPnya dipandang cukup mampu untuk menghitung sendiri serta menentukan jumlah pajak terutangnya sendiri. Misalnya Pajak Penghasilan ( $\mathrm{PPh}$ ), Pajak Pertambahan Nilai (PPN), Pajak Penjualan Atas Barang Mewah (PPnBM).

Keempat, Sistem Withholding ialah suatu sistem dalam pemungutan pajak yang memberikan

\footnotetext{
${ }^{8}$ A. Anshari Ritonga. (2017). Pengantar Ilmu Hukum Pajak
} \& Perpajakan Indonesia. Jakarta: Pustaka El Manar, h. 61. kewenangan kepada pihak ketiga, baik itu pemotong pajak atau pemungut pajak yang memotong/ memungut utang pajak.

Pada sistem ini fiskus hanya melakukan pengawasan terhadap pihak ketiga yang melakukan pemotongan/pemungutan pajak yang terutang. Selain itu, Indonesia sebagai negara hukum, dalam melakukan pemungutan pajak harus berdasarkan suatu landasan hukum yaitu peraturan perundangundangan perpajakan, syarat ini disebut dengan syarat yuridis yaitu bahwa hukum pajak harus dapat memberikan jaminan atau kepastian hukum baik bagi warga negara maupun bagi warganya. Pemungutan pajak di Indonesia diatur pada UUD NRI 1945 pada Pasal 23 tepatnya di ayat (2) yang menyatakan: "Pengenaan dan pemungutan pajak hanya untuk keperluan negara hanya boleh terjadi (dilakukan) berdasarkan undang-undang."

Atas pemungutan pajak tersebut, wajib pajak harus membayar utang pajaknya tersebut. Utang pajak dapat timbul karena terpenuhinya suatu taatbestand (peristiwa/keadaan/perbuatan tertentu), ${ }^{9}$ atau ketika dikeluarkannya Surat Ketetapan Pajak. ${ }^{10}$

Wajib pajak merupakan subjek perpajakan yang sudah memenuhi syarat subjektif, sebagaimana diatur dalam masing-masing peraturan perundang-undangan masing-masing pajak terkait subjek pajak, dan juga memenuhi syarat objektif yaitu terpenuhinya suatu taatbestand (peristiwa/keadaan/perbuatan tertentu) ataupun ketika diterbitkannya surat ketetapan pajak. Pengertian wajib pajak diatur pada Pasal 1 tepatnya di angka 2, UU No. 6 Tahun 1983 sebagaimana telah diubah beberapa kali, terakhir dengan UU No. 16 Tahun 2009 tentang Ketentuan-Ketentuan Umum dan Tata Cara Perpajakan (selanjutnya disebut UU KUP), ialah orang perorangan (orang pribadi) atau badan, yang meliputi diantaranya pihak yang membayar pajak, pihak yang melaksanakan pemotongan pajak, dan pihak yang melaksanakan pemungutan pajak, yang memiliki hak serta kewajiban pajak sebagaimana diatur dalam ketentuan perundangundangan perpajakan yang berlaku. Sehingga, WP dalam sistem hukum perpajakan di Indonesia

\footnotetext{
${ }^{9}$ Sartan G. (1980). Perpajakan Pengantar Hukum Pajak Positip di Indonesia. Semarang: Djambatan, h. 14.

${ }^{10}$ Marihot P. Siahaan. (2004). Utang Pajak, Pemenuhan Kewajiban, dan Penagihan Pajak Dengan Surat Paksa. Jakarta: Raja Grafindo Persada, h. 128.
} 
berkedudukan sebagai pihak yang memikul beban tanggung jawab guna membayar utang pajaknya.

Selain itu, di dalam sistem hukum perpajakan serta peraturan mengenai perpajakan juga mengatur mengenai subjek pajak lain, yaitu penanggung pajak. Pengertian penanggung pajak diatur pada Pasal 1 tepatnya diangka 28 UU KUP, ialah orang perorangan (orang secara pribadi) ataupun badan yang memikul beban tanggung jawab untuk melaksanakan pembayaran pajak, termasuk wakilnya yang melaksanakan hak dan menjalankan kewajiban di bidang perpajakan WP berdasarkan ketentuan perpajakan yang berlaku.

Pada dasarnya penanggung pajak bukan merupakan Wajib Pajak, berarti pihak yang mempunyai pajak terutang adalah Wajib Pajak dan bukan penanggung pajak. Penanggung pajak hanya berkedudukan sebagai pengganti WP untuk memenuhi tanggung jawab pembayaran utang pajak WP. Pengertian penanggung pajak lebih luas daripada WP itu sendiri. WP ialah orang perorangan yang namanya tercantum namanya dalam SKP, dan untuk penanggung pajak ialah orang-orang yang memikul beban tanggung jawab untuk membayar pajak terutang. Pihak-pihak yang memikul beban tanggung jawab terhadap pajak terutang, bukan hanya WP saja melainkan pula orang atau badan lainnya. Sehingga, pihak lainnya, selain pihak yang tercantum namanya di dalam SKP (Surat Ketetapan Pajak), dapat pula ditunjuk penanggung pajak lainnya yang ditetapkan oleh undang-undang pajak. ${ }^{11}$

Ditinjau dari penjelasan tersebut, penanggung pajak merupakan wakil yang menjalankan kewajiban perpajakan dari wajib pajak, ketika wajib pajak tersebut tidak dapat memenuhi kewajiban perpajakannya sendiri. Dalam sistem hukum perpajakan di negara ini Penanggung Pajak memiliki kedudukan sebagai wakil dari wajib pajak.

\section{Penyanderaan dan Para Pihak Yang Memikul Beban Tanggung Jawab Saat Upaya Penyanderaan Dilaksanakan}

Dalam sistem pelaksanaan pemungutan pajak yang digunakan di Indonesia adalah Sistem Self Assessment. Sistem pemungutan merupakan sistem yang mana pemerintah pusat maupun Pemda mempercayakan kepada WP untuk melakukan

\footnotetext{
11 ibid., h. 15.
}

penghitungan, penyetoran dan melaksanakan pelaporan kewajiban di bidang perpajakannya secara mandiri. WP dalam hal ini dianggap telah dapat melakukan penghitungan atas pajak yang terutang, mampu memahami peraturan perundang-undangan perpajakan. $^{12}$

Dalam penerapan self assessment system memungkinkan potensi dimana WP untuk tidak menjalankan kewajiban perpajakannya berdasarkan ketentuan yang diatur dalam peraturan perpajakan di Indonesia, baik karena kelalaian, kesengajaan atau karena ketidaktahuan WP terhadap kewajiban perpajakannya. ${ }^{13}$ Maka dari itu, masih diperlukan suatu upaya dari negara untuk melakukan penagihan pajak, yaitu melalui mekanisme penagihan pajak melalui penerbitan Surat Paksa. Dalam upaya penagihan dengan surat paksa, terdapat beberapa tindakan yang dapat dilaksanakan agar Penanggung Pajak membayar utang pajaknya. Tindakan-tindakan tersebut adalah Surat Paksa, Penyitaan (dapat disertai dengan penjualan secara lelang), serta Pencegahan dan Penyanderaan.

Lembaga penyanderaan (paksa badan) dalam hukum pajak dilatarbelakangi oleh adanya kepentingan negara untuk mencairkan tunggakantunggakan utang pajak melalui penagihan hingga tuntas. ${ }^{14}$ Penyanderaan dalam sisten hukum pajak yang ada di Indonesia merupakan langkah terakhir yang dijalankan ketika Penanggung Pajak tidak memenuhi kewajiban perpajakan yaitu pembayaran pajak. Kegiatan penyanderaan merupakan upaya yang berbeda dibandingkan dengan kegiatan penagihan pajak lainnya, dalam penyanderaan, yang dijadikan sebagai jaminan untuk melunasi pajak yang terutang adalah kebebasan diri dari Penanggung Pajak. ${ }^{15}$

Lembaga penyanderaan atau Gijzeling dikenal pula dengan sebutan Lifsdwang atau "paksa badan"

\footnotetext{
${ }^{12}$ Widi Widodo. (2010). Moralitas, Budaya, dan Kepatuhan Pajak. Bandung: Alfabeta, h. 148.

${ }^{13}$ Khoirul Hidayah dan Mudawamah. (2015). Gijzeling dalam Hukum Pajak di Indonesia Kajian Peraturan PerundangUndangan dan Integrasi Islam. Malang: UIN-Maliki Press, h. 3.

${ }^{14}$ Rini Irianti Sundary. (2003). "Kebijakan Menerapkan "Lembaga Paksa Badan (Gijzeling)" Dalam Rangka Penegakan Hukum Pajak Dalam Perspektif Hak Asasi Manusia dan Hukum Islam”. Jurnal Mimbar. Universitas Islam Bandung. Vol. 19 No. 4, h. 422 .

${ }^{15}$ Khoirul Hidayah dan Mudawamah. op.cit., h. 133.
} 
atau "Sandera Badan". Istilah Gijzeling itu sendiri berasal dari istilah Belanda yang berarti "sandra" ${ }^{16}$

Lembaga penyanderaan dipergunakan sebagai alat paksa dalam penagihan utang pajak, karena pajak termasuk dalam hukum publik, yang mengatur kewajiban dan hak warga negara terhadap masyarakat. ${ }^{17}$ Penyanderaan sebagai langkah untuk menagih pajak tidak dapat dilakukan terhadap semua Penanggung Pajak yang mewakili WP yang mempunyai utang pajak, dikarenakan penyanderaan merupakan tindakan pengekangan sementara kebebasan penanggung pajak. Untuk itu demi terciptanya keadilan maka dalam melakukan penyanderaan harus memenuhi persyaratan yaitu yang sifatnya kuantitatif, yaitu mempunyai pajak terutang dengan nominal tertentu, serta syarat kualitatif yaitu penanggung pajak yang diragukan itikad baiknya dalam hal pelunasan utang pajaknya. ${ }^{18}$

Dasar pertimbangan untuk melakukan penyanderaan dapat berasal dari informasi/data-data yang rinci dan akurat mengenai status, kredibilitas, catatan mengenai karakter WP maupun penanggung pajak dalam memenuhi kewajiban perpajakannya pada tahun-tahun sebelumnya, yang diperoleh dari kantor pajak setempat maupun dari hasil pemeriksaan yang pernah dilakukan oleh petugas pemeriksa. ${ }^{19}$

Hal tersebut sebagaimana diatur dalam Pasal 33 ayat (1) pada UU No. 19 Tahun 1997 yang telah diubah Dengan UU No. 19 Tahun 2000 tentang Penagihan Pajak melalui Surat Paksa (selanjutnya disebut UU PPSP), yaitu: tindaka Penyanderaan hanya bisa dilaksanakan kepada penanggung pajak yang memiliki pajak terutang minimal Rp.100.000.000,00 (seratus juta rupiah) serta itikad baik untuk melunasi pajak terutang diragukan. Penyanderaan dilakukan apabila telah melampaui waktu selama 14 (empat

${ }^{16}$ Galang Asmara. (2006). Peradilan Pajak \& Lembaga Penyanderaan (Gijzeling) dalam Hukum Pajak di Indonesia. Yogyakarta: LaksBang PRESSindo, h. 137.

${ }^{17}$ Budi Ispriyarso. (2015). "Sandera Pajak Sebagai Alat Paksa Dalam Penagihan Utang Pajak (Studi tentang Penegakan Hukum Pajak Melalui Sandera Pajak)”. Jurnal Masalah-Masalah Hukum. Jilid 44 No. 1, h. 72.

${ }^{18}$ Marihot P. Siahaan. op.cit., h. 569.

${ }^{19}$ Norma R.K.Z., Budi Ispriyarso, F.C. Susila Adiyanta. (2016). "Penagihan Pajak dengan Menggunakan Sandera Pajak (Gijzeling) di Lingkungan Kerja Kantor Wilayah Direktorat Jenderal Pajak Jawa Tengah I dan Kantor Wilayah Direktorat Jenderal Pajak Jawa Tengah II". Jurnal Diponegoro Law Review. Vol. 5 No. 2, h. 7. belas) hari yang terhitung mulai tanggal surat paksa telah diberitahukan oleh pemungut pajak kepada penanggung pajak.

Ketentuan terkait petunjuk penanggung pajak yang itikad baiknya masih diragukan untuk melaksanakan pelunasan utang pajak diatur dalam Pasal 3 ayat (1) huruf d, Keputusan Dirjen Pajak No. KEP-218/PJ/2003 tentang Petunjuk terkait Pelaksanaan Penyanderaan dan Pemberian Rehabilitasi Nama Baik Penanggung Pajak (selanjutnya disebut KEP-218/PJ/2003), yaitu:

Pertama, Anjuran untuk melunasi pajak yang terutang tidak direspon oleh Penanggung Pajak;

Kedua, Penanggung Pajak tidak berkenan untuk membayar pajak yang terutang baik itu dengan mengangsur ataupun melunasi sekaligus;

Ketiga, Penanggung Pajak tidak mau untuk menyerahkan harta bendanya untuk membayar lunas utang pajak;

Keempat, Penanggung pajak berkeinginan untuk meninggalkan negara Indonesia untuk waktu lama ataupun memiliki niat untuk melakukan hal tersebut;

Kelima, Penanggung Pajak akan menjual, menghibahkan atau hal lain yang berkaitan dengan pengalihan harta bendanya baik yang dimiliki ataupun dikuasainya untuk menutup atau merampingkan kegiatan usaha maupun pekerjaan yang dijalankannya di negara Indonesia;

Keenam, Penanggung Pajak berniat untuk menutup kegiatan usaha ataupun melakukan penggabungan usahanya, atau melebarkan bidang usaha yang dijalankannya atau melakukan pemindah tanganan perusahaan yang dikuasai maupun dipunyainya atau merubah usahanya ke bentuk lainnya.

Selain syarat kuantitatif dan syarat kualitatif, tindakan penyanderaan juga perlu mendapatkan persetujuan secara tertulis oleh Menteri Keuangan dalam melaksanakan kegiatan penagihan pajak pemerintah pusat dan Gubernur/Kepala Daerah Provinsi untuk pajak daerah sebagaimana diatur Pada Pasal 33 ayat (2) UU PPSP. Dengan perlunya untuk mendapatkan izin untuk pelaksanaan penyanderaan, diharapkan pejabat tidak bertindak sewenang-wenang dalam melakukan tindakan penyanderaan.

Segera setelah menerima persetujuan secara tertulis oleh Menteri Keuangan ataupun Gubernur/ Kepala Daerah Tingkat I, maka Kepala Kantor Pajak 
menerbitkan Surat untuk perintah penyanderaan. Surat yang memuat perintah untuk melaksanakan penyanderaan yang dikeluarkan oleh kepala kantor sekurang-kurangnya memuat: a. Identitas Penanggung Pajak; b. Alasan penyanderaan; c. Izin penyanderaan; d. Lamanya penyanderaan; e. Tempat penyanderaan.

Masa penyanderaan yang ditetapkan dalam Pasal 33 ayat (3) UU PPSP adalah untuk waktu paling lama selama 6 (enam) bulan serta dapat untuk dilakukan perpanjangan untuk waktu untuk paling lama 6 (enam) bulan.

Tindakan penyanderaan mulai dilaksanakan pada saat Surat Perintah Penyanderaan diterima oleh Penanggung Pajak yang disandera. Ketika Penanggung Pajak menolak untuk menerima surat yaitu perintah untuk tindakan penyanderaan yang diserahkan oleh Juru Sita Kantor Pajak, maka Juru Sita menaruh Surat Perintah tersebut di tempat tinggal ataupun tempat Penanggung Pajak bekerja serta mencatat hal tersebut di dalam Berita Acara yaitu Penyampaian Surat untuk melakukan penyanderaan, maka Surat Perintah untuk melakukan penyanderaan dianggap telah disampaikan dan diterima serta syah dan mempunyai kekuatan yang mengikat secara hukum.

Penanggung Pajak dari WP yang telah disandera dimasukkan di suatu tempat tertentu yang menjadi tempat untuk tindakan penyanderaan yang memenuhi syarat-syarat: a. Jauh dari masyarakat serta tertutup; b. Mempunyai fasilitas terbatas; c. Memiliki sistem dalam pengamanan serta pengawasan yang cukup baik.

Apabila tempat untuk upaya penyanderaan tersebut belum terbentuk, Penanggung dari WP dalam keadaan disandera dititipkan sementara waktu di rumah tahanan serta berada secara terpisah dari tanahan kejahatan yang lain (tahanan terpidana). Kepala Rumah Tahanan Negara wajib menerima Penanggung dari WP yang telah disandera berdasarkan Surat Perintah Penyanderaan, sebagaimana diatur dalam Pasal 3 ayat (2) Keputusan Bersama Menkeu serta Menteri Kehakiman dan HAM No. 294/KMK.03/2003, dan No. M-02. UM.09.01 Tahun 2003 terkait Tata Cara untuk melakukan Penitipan Penanggung dari Wajib Pajak yang Disandera Di Dalam Rumah Tahanan Dalam
Rangka Untuk Melaksanakan Penagihan Pajak melalui Surat Paksa.

Dalam UU PPSP diatur bahwa pihak yang memikul beban tanggung jawab apabila dilaksanakannya upaya penyaderaan hanyalah penanggung dari WP atau wakil dari WP. Sehingga dalam hal ini seolah-olah WP yang memiliki pajak terutang bebas dari beban untuk bertangungjawab apabila dilakukan upaya penyanderaan. Sehingga seharusnya yang memikul beban tanggung jawab tersebut ialah WP, baik itu WP orang perorangan maupun WP badan. Untuk wajib pajak orang pribadi, yang memikul beban tanggung jawab ialah WP orang perorangan yang memiliki utang pajak tersebut, sepanjang WP orang perorangan tersebut telah dewasa dan tidak dalam pengampuan. Untuk WP yang merupakan orang pribadi, yaitu anakanak yang masih di bawah umur atau belum dewasa ataupun orang-orang di bawah pengampuan, yang memikul beban tanggung jawab ialah wakilnya yaitu wali atau pengampunya yang berkedudukan sebagai penanggung pajak, sedangkan untuk WP berbentuk badan tentunya tidak dapat menjalankan kewajiban perpajakannya sendiri sehingga dalam hal ini diwakili oleh penanggung pajak. Pihak yang termasuk dalam penanggung pajak untuk wajib pajak badan diatur dalam Pasal 32 ayat (1) huruf a, huruf b, huruf c, huruf d pada UU KUP, yaitu: a. Badan oleh pengurus; $b$. Badan yang sedang dalam keadaan pailit diwakili oleh seorang kurator; c. Badan yang sedang dalam proses pembubaran diwakili oleh seseorang ataupun badan yang diberi tugas untuk melaksanakan pemberesan pada badan tersebut; d. Badan yang dalam keadaan likuidasi diwakili oleh likuidator.

Pengurus sebagai penanggung pajak, wajib pajak badan dijelaskan lebih lanjut dalam Surat Edaran Dirjen Pajak Nomor SE-02/PJ/2017 tentang Petunjuk Pelaksanaan Permenkeu No. 229/PMK.03/2014 terkait Syarat-Syarat dan Tata Cara Pelaksanaan Hak serta Kewajiban Dari Seorang Kuasa, yaitu: Pengurus suatu badan adalah orang-orang yang memikul beban tanggung jawab secara penuh untuk melaksanakan tindakan pengurusan badan baik itu untuk kepentingan badan serta sesuai dengan maksud maupun tujuan dari dibentuknya badan tersebut, serta yang mewakili badan tersebut baik itu di dalam ataupun di luar dari pengadilan, yang dapat dibuktikan dengan surat-surat atau dokumen 
yaitu akta pendirian badan dan/atau surat-surat atau dokumen lainnya yang dipersamakan dengan surat atau dokumen tersebut.

Pihak yang termasuk ke dalam kategori pengurus dari WP badan tersebut ialah orang-perorangan yang terbukti secara nyata memiliki kewenangan untuk mengambil kebijakan dan/atau membuat suatu keputusan yang berkaitan dengan jalannya kegiatan usaha dari perusahaan dan orang-orang yang mendapatkan kewenangan dalam menjalankan kepengurusan perusahaan tersebut demi kepentingan dari perusahaan yang didasarkan pada maksud serta tujuan dari badan, yang mana hal-hal tersebut dibuktikan dengan surat keterangan dari pimpinan yang berwenang yang menjelaskan keadaan demikian. Orang perorangan yang masuk dalam kategori pengertian dari pengurus badan adalah seorang komisaris, orang yang memiliki saham terbanyak atau pengendali, orang yang memiliki saham, ataupun karyawan dari WP badan tersebut, atau pihak-pihak lainnya, sepanjang ia telah terbukti secara nyata memiliki kewenangan untuk mengambil kebijakan dan/ataupun membuat keputusan untuk melaksanakan kegiatan dari perusahaan.

Dalam sistem hukum perpajakan di Indonesia, hal-hal yang mengatur subjek hukum perpajakan terkait dengan tanggung jawab badan atau korporasi dipengaruhi oleh teori tanggung jawab diantaranya Strict Liability, Vicarious Liability serta Corporate Cultural Model. ${ }^{20}$ Dalam teori tanggung jawab Strict Liability beban pertanggungjawaban suatu badan atau korporasi didasarkan pada peraturan perundangundangan, yang dapat diartikan bahwa tanggung jawab suatu badan berada pada kedudukan para pihak dalam korporasi atau badan tersebut sehingga beban pertanggungjawaban dipikul oleh subjek hukum pada kedudukannya dalam badan tersebut. Untuk teori Vicarious Liability (pertanggungjawaban pengganti) pengaturannya dalam UU KUP dapat dilihat pada Pasal 32 ayat (1) dalam hal menjalankan hak dan memenuhi kewajiban perpajakan WP Badan oleh Pengurus, sehingga dalam hal ini yang memikul beban tanggungjawab perpajakan adalah pengurus.

${ }^{20}$ Nindi Achid Arifki dan Ilima Fitri Azmi. (2018). "Pertanggungjawaban Korporasi Dalam Penyelesaian Sengketa Perpajakan: Suatu Kajian Hukum Doktrinal". Jurnal Administrasi Negara. Vol. 24 No. 1, h. 43.
Teori berikutnya yaitu Corporate Cultural Model adalah teori yang berfokus pada kebijakan badan hukum yang tersirat maupun yang tersurat memberikan izin atau kewenangan kepada seseorang dengan dasar yang jelas, ${ }^{21}$ sehingga dapat disimpulkan bahwa seseorang, meskipun tidak disebutkan namanya dalam akta pendirian maupun perubahan tetap dapat menjalankan kebijakan badan dikarenakan telah diberikan izin baik secara tersirat (sepanjang dapat dibuktikan) maupun tersurat oleh badan atau korporasi tersebut.

Selain teori tanggungjawab tersebut di atas dalam hukum perpajakan khususnya terkait Penagihan Pajak dengan Surat Paksa juga dikenal teori Lifting the Corporate Veil. ${ }^{22}$ Teori ini memberi pandangan bahwa dalam memenuhi kewajiban perpajakan suatu badan sebagai contoh yaitu perseroan terbatas memiliki cakupan lebih luas dibandingkan dengan Undang-Undang Nomor 40 Tahun 2007 tentang Perseroan Terbatas, sehingga tidak hanya Direksi yang dapat dibebani tanggungjawab untuk memenuhi kewajiban perpajakan, tetapi juga mencakup pemegang saham, bahkan seseorang yang meskipun namanya tidak tercantum dalam akta pendirian maupun perubahan sepanjang dapat dibuktikan dia memiliki kewenangan dalam mengambil kebijakan dalam badan tersebut. Hal ini pun dianut oleh UU PPSP yang dirincikan lebih lanjut dalam Surat Edaran Dirjen Pajak Nomor SE-02/PJ/2017 tentang Petunjuk Pelaksanaan Permenkeu No. 229/PMK.03/2014 terkait Syarat-Syarat dan Tata Cara Pelaksanaan Hak serta Kewajiban Dari Seorang Kuasa.

Tanggungjawab dari pihak-pihak yang menjadi penanggung pajak sebagaimana dijabarkan dalam Surat Edaran Dirjen Pajak Nomor SE-02/PJ/2017 tentang Petunjuk Pelaksanaan Permenkeu No. 229/ PMK.03/2014 terkait Syarat-Syarat dan Tata Cara Pelaksanaan Hak serta Kewajiban Dari Seorang Kuasa memiliki beban tanggungjawab untuk memenuhi kewajiban perpajakan dari WP. Terkait pihak mana yang akan disandera adalah berdasarkan pertimbangan dari Kepala Kantor Pelayanan Pajak sebagai pihak yang menerbitkan Surat Perintah Penyanderaan.

\footnotetext{
21 ibid., h. 45.

22 ibid.
} 
Upaya Hukum Yang Dapat Ditempuh Penanggung Pajak Yang Dilakukan Tindakan Penyanderaan (Gijzeling)

Terhadap Penanggung Pajak yang dilakukan tindakan Penyanderaan (Gijzeling), sebagaimana diatur dalam UU PPSP pada Pasal 34 ayat (3) Jo. Peraturan Pemerintah Nomor 137 Tahun 2000 tentang Tempat dan Tata Cara Penyanderaan, Rehabilitasi Nama Baik Penanggung Pajak, dan Pemberian Ganti Rugi Dalam Rangka Penagihan Pajak dengan Surat Paksa Pasal 15 ayat (1) yang pada intinya mengatur bahwa Penanggung Pajak yang disandera dapat mengajukan gugatan terhadap pelaksanaan penyanderaan hanya kepada Pengadilan Negeri.

Apabila gugatan yang diajukan Penanggung Pajak tersebut dikabulkan oleh pengadilan serta putusan tersebut telah berkekuatan hukum tetap (Inkracht), maka Penanggung Pajak dapat mengajukan permohonan rehabilitasi nama baik dan ganti rugi sebagaimana diatur dalam Pasal 16 ayat (1) Peraturan Pemerintah Nomor 137 Tahun 2000 tentang Tempat dan Tata Cara Penyanderaan, Rehabilitasi Nama Baik Penanggung Pajak, dan Pemberian Gantu Rugi Dalam Rangka Penagihan Pajak dengan Surat Paksa. Permohonan rehabilitasi dan ganti rugi tersebut diajukan kepada Pejabat yang menerbitkan Surat Perintah Penyanderaan.

Rehabilitasi nama baik dilaksanakan oleh Pejabat dengan membuat pengumuman pada media cetak harian yang berskala nasional dengan ukuran yang mudah terlihat sebanyak 1 (satu) kali dalam jangka waktu paling lambat 30 (tiga puluh) hari sejak diterimanya permohonan Rehabilitasi oleh Pejabat yang menerbitkan Surat Perintah Penyanderaan. Berikutnya untuk besaran ganti kerugian yang diberikan oleh Pejabat kepada Penanggung Pajak adalah sebesar Rp100.000,00 (seratus ribu rupiah) per hari selama masa penyanderaan yang telah dijalani oleh Penanggung Pajak. Ganti rugi tersebut diberikan oleh Pejabat kepada Penanggung Pajak paling lama 30 (tiga puluh) tiga puluh hari sejak permohonan rehabilitasi tersebut diterima oleh Pejabat yang menerbitkan Surat Perintah Penyanderaan.

\section{PENUTUP}

\section{Kesimpulan}

Pihak-pihak yang menjadi Penanggung Pajak sebagaimana dijabarkan dalam UU KUP yaitu pengurus untuk WP Badan, kutaror untuk Badan dalam keadaan Pailit, Badan yang sedang dalam proses pembubaran diwakili oleh seseorang ataupun badan yang diberi tugas untuk melaksanakan pemberesan pada badan tersebut, untuk Badan yang dalam keadaan likuidasi diwakili oleh likuidator. Orang perorangan yang masuk dalam kategori pengertian dari pengurus badan adalah seorang komisaris, orang yang memiliki saham terbanyak atau pengendali, orang yang memiliki saham, ataupun karyawan dari WP badan tersebut, atau pihak-pihak lainnya, sepanjang ia telah terbukti secara nyata memiliki kewenangan untuk mengambil kebijakan dan/ataupun membuat keputusan untuk melaksanakan kegiatan dari perusahaan.

Di saat terjadi upaya penyanderaan, maka yang memikul beban tanggung jawab ialah wajib pajak, baik itu WP orang perorangan maupun wajib pajak badan. Ketika WP orang perorangan tersebut adalah anak yang masih di bawah umur atau orang-orang yang sedang berada di bawah pengampuan yang memikul beban tanggung jawab apabila dilakukan tindakan penyanderaan ialah wakilnya yaitu wali atau pengampu sebagai penanggung pajak. Untuk wajib pajak badan, tentunya tidak dapat memenuhi kewajiban perpajakannya sendiri, sehingga diwakili oleh penanggung pajak, yaitu Pengurus. Dalam hal akan dilakukan tindakan penyanderaan terhadap pengurus yang merupakan wakil dari WP Badan maka setiap pengurus sebagaimana dijelaskan di atas memiliki beban tanggung jawab yang sama, terkait siapa di antara pengurus tersebut yang akan dikenakan tindakan penyanderaan adalah berdasarkan Kepala Kantor Pelayanan Pajak sebagai pihak yang mengeluarkan Surat Perintah Penyanderaan.

\section{Rekomendasi}

Pemerintah perlu melakukan perubahan terkait UU PPSP dikarenakan peraturan tersebut hanya mencantumkan Penanggung Pajak sehingga timbul pemikiran bahwa hanya Penanggung Pajak yang memikul beban tanggung jawab dalam upaya penagihan pajak melalui surat paksa hanyalah penanggung pajak yang seyogyanya merupakan pengganti dari WP dalam keadaan tertentu. Hal tersebut yang jika dibiarkan, dapat berakibat WP untuk bebas dari beban tanggung jawabnya apabila dilaksanakannya penagihan pajak. Di samping itu, 
pemerintah perlu lebih meningkatkan sosialisasi hukum dan penyuluhan terkait hak serta kewajiban di bidang pajak kepada masyarakat, dengan harapan masyarakat sebagai wajib pajak dapat membayar pajaknya, yang tentunya dapat menambah pendapatan negara.

\section{DAFTAR PUSTAKA}

\section{Peraturan Perundang-undangan:}

Undang-Undang Dasar Tahun 1945.

Undang-Undang No. 6 Tahun 1983 yang beberapa kali diubah, terakhir dengan Undang-Undang No. 16 Tahun 2009 tentang Ketentuan-Ketentuan Umum serta Tata Cara Perpajakan.

Undang-Undang No. 7 Tahun 1983 sebagaimana terakhir diubah dengan Undang-Undang No. 36 Tahun 2008 tentang PPh.

Undang-Undang No. 19 Tahun 1997 sebagaimana telah diubah dengan Undang-Undang No. 19 Tahun 2000 tentang Penagihan Pajak Melalui Surat Paksa.

Peraturan Pemerintah No. 137 Tahun 2000 tentang Tempat dan Tata Cara Penyanderaan, Rehabilitasi Nama Baik Penanggung Pajak, dan Pemberian Ganti Rugi Dalam Rangka Penagihan Pajak Dengan Surat Paksa.

Keputusan Bersama Menkeu serta Menteri Kehakiman dan HAM No. 294/KMK.03/2003, dan No. M-02.UM.09.01 Tahun 2003 tentang Tata Cara Penitipan Penanggung Pajak yang Disandera Di Rumah Tahanan Negara Dalam Rangka Penagihan Pajak dengan Surat Paksa.

Keputusan Dirjen Pajak No. KEP-218/PJ/2003 tentang Petunjuk Dalam Pelaksanaan Penyanderaan serta Pemberian Rehabilitasi Nama Baik Penanggung Pajak.

Surat Edaran Dirjen Pajak Nomor SE-02/PJ/2017 tentang Petunjuk Pelaksanaan Permenkeu No. 229/PMK.03/2014 tentang Syarat-Syarat dan Pemenuhan Hak dan Kewajiban Dari Seorang Kuasa

\section{Buku:}

A. Anshari Ritonga. (2017). Pengantar Ilmu Hukum Pajak \& Perpajakan Indonesia. Jakarta: Pustaka El Manar.

Erly Suandy. (2016). Hukum Pajak Edisi 7. Jakarta: Salemba Empat.
Galang Asmara. (2006). Peradilan Pajak \& Lembaga Penyanderaan (Gijzeling) dalam Hukum Pajak di Indonesia. Yogyakarta: LaksBang PRESSindo.

Ida Zuraida dan L.Y. Hari Sih Advianto. (2011). Penagihan Pajak: Pajak Pusat dan Pajak Daerah. Bogor: Ghalia Indonesia.

Khoirul Hidayah dan Mudawamah. (2015). Gijzeling dalam Hukum Pajak di Indonesia Kajian Peraturan Perundang-Undangan dan Integrasi Islam. Malang: UIN-Maliki Press.

Marihot P. Siahaan. (2004). Utang Pajak, Pemenuhan Kewajiban, dan Penagihan Pajak Dengan Surat Paksa. Jakarta: Raja Grafindo Persada.

Peter Mahmud Marzuki. (2005). Penelitian Hukum. Jakarta: Prenada Media.

Sartan G. (1980). Perpajakan Pengantar Hukum Pajak Positip di Indonesia. Semarang: Djambatan.

Widi Widodo. (2010). Moralitas, Budaya, dan Kepatuhan Pajak. Bandung: Alfabeta.

Wirawan B. Ilyas dan Richard Burton. (2010). Hukum Pajak Edisi 5. Jakarta: Salemba Empat.

\section{Jurnal:}

Budi Ispriyarso. (2015). "Sandera Pajak Sebagai Alat Paksa Dalam Penagihan Utang Pajak (Studi tentang Penegakan Hukum Pajak Melalui Sandera Pajak)". Masalah-Masalah Hukum. Jilid 44 No. 1.

Nindi Achid Arifki dan Ilima Fitri Azmi. (2018). "Pertanggungjawaban Korporasi Dalam Penyelesaian Sengketa Perpajakan: Suatu Kajian Hukum Doktrinal". Administrasi Negara. Vol. 24 No. 1

Norma R.K.Z., Budi Ispriyarso, F.C. Susila Adiyanta. (2016). "Penagihan Pajak dengan Menggunakan Sandera Pajak (Gijzeling) di Lingkungan Kerja Kantor Wilayah Direktorat Jenderal Pajak Jawa Tengah I dan Kantor Wilayah Direktorat Jenderal Pajak Jawa Tengah II". Diponegoro Law Review. Vol. 5 No. 2.

Rini Irianti Sundary. (2003). "Kebijakan Menerapkan "Lembaga Paksa Badan (Gijzeling)" Dalam Rangka Penegakan Hukum Pajak Dalam Perspektif Hak Asasi Manusia dan Hukum Islam". Jurnal Mimbar. Bandung: Universitas Islam Bandung. Vol. 19 No. 4. 